\title{
Implementation of Cashless Economy: Measuring the Impact of Awareness and Advantages with Problems with Reference to North India
}

\author{
Amit Uniyal, Rupa Khanna, Ranjit Mukherji, Shipra Gupta
}

\begin{abstract}
A new flagship programme was propelled by the government of India called "The Digital India Programme" to enhance and with a vision to transform the economy of the country into a "Faceless, Paperless, Cashless" economy. RBI is having a major role to play and support the government in achieving the goals. In this study we had tried to study the impact of various factors like awareness, advantages and problems in the cashless economy in India and the impact of awareness and advantages on the problems. The empirical study found that all the three factors have their own importance and impact on the cashless economy. There are other factors also which have an impact on cashless economy. In India it is at its adolescent stage.
\end{abstract}

Keywords: Demonetization; Cashless; IMPS; NEFT; RTGS; AEPS; point of sale.

\section{INTRODUCTION}

The use of electronic money media for the payments of purchases, Immediate Payment Service (IMPS), National Electronic Funds Transfer (NEFT) and Real Time Gross Settlement (RTGS). and other transactions we call it as cashless transaction or cashless economy. Our money will be in possession of the third party, he allows us to do the transaction and he can use the money when the money is not needed by us. We also use different instruments and technologies like credit cards, debit cards, mobile phones handsets to pay money into other accounts or transfer the money from one account to other bank or in the same bank in different account online without actually using the hard cash. Indian Government has propelled a lead program ${ }_{\mathrm{i}}$ called "The Digital India Program" to enhance and with a vision to transform the economy of the country with a role $\mathrm{iii}_{\text {. }}$ of " Faceless, Paperless, Cashless" economy. Pour P.M. Mriv. Narendra Modi is the one who has pitched issue and took the decision for converting the country's economy in to a cashless economy. By demonetizing the Rs500 and Rs. 1000 currency notes the government has tried to bring a drastic change in the country's economy on Nov. $8^{\text {th }} .2016$ But there has been many implications and illusions amongst the people whether the existing government would be able to push the economy into the every changing environment. The cash operations cost incurred by RBI and commercial banks is about 21,000 corers per annum in India. Study by Tufts University (2014). Other reason like the ratio between the cash and the gross domestic product in India is highest in the world i.e. $12.42 \%$ in GDP.

Revised Manuscript Received on October 20, 2019.

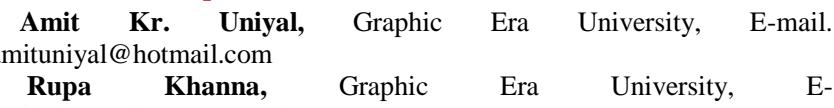
mail.dr.rupakhanna@gmail.com

Ranjit Kr. Mukherji, Graphic Era University, Dehradun, E-mail rkmmukh@gmail.com

Shipra Gupta, Associate Profesor, Department of commerce, Graphic Era Hill University, Dehradun
The following data represents the amount of currency circulation in the different countries of the world- $9.47 \%$ China, $4 \%$ - Brazil. Currency notes in circulation in India are 76.47 billion which is quite high as compared to other big economies like U.S. (34.5 billion in 2012-13).

There are various other reasons like decreasing the paper cost, making it difficult for tax evaders, making people open their bank accounts since a large segment of the people did not had their bank accounts in India. The benefits of direct transfer to be provided for these who are using online transactions to reduce the hard cash transactions and to increase transparency.

To boost the system of cashless economy in the country small finance banks and payments banks have been issued licenses by the RBI with a view to push financial inclusion and bring innovative banking solutions. Aiming to improve the monetary policy, inflation and the pricing system of the country, to improvise, Some schemes were launched are like: Janlakshmi- $29^{\text {th }}$ April 2017, Suryoday- $23^{\text {rd }}$. Jan'2017, Ujjivan- $11^{\text {th }}$. Nov 2016

To make the digital transactions National Payments Corporation of India launched Unified payments Interface it is as simple as sending a text message.

Some hurdles in the path of Indian Economy to become a Cashless Economy:

Most of the part of the population is still not yet covered with the adequate net services on which our cashless environment depends.

Points of sales which are accepting payments through cards are only 1.46 million points.

The unorganized sector covers the $90 \%$ of the workforce.

Converting cashless from a followed tradition system in the informal sector is a tedious task. In order to evade taxes in India the merchants are generally in a habit not to keep a written or any record of their transactions. According to a report (2015)- To bring an unbanked population of 233 million under the banking system would not be easy in India. The other factors which have to be analyzed are awareness, technological developments and government interventions on which the future of transactions depends. Also the people in general find it convenient to pay in cash and the businessmen and the traders do not generally keep a record of the transactions/income which directly pave way to black money and evade tax. The other factors on which the cashless economy depends directly are the availability and the quality of telecom network in urban as well in rural India since problems are being faced in doing online transactions even in metro cities, which require a serious thought being the basic requirement for a cashless economy.

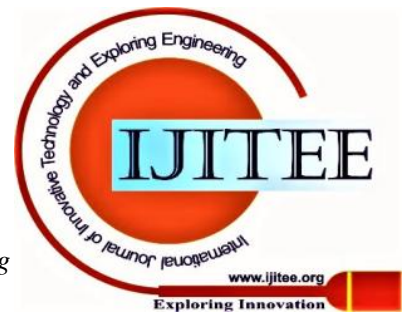


The real problems which have to be encountered are:

i. Half of the population is still not connected with any of the banks.

ii. Internet Facilities not suitable.

iii. There are more than 350 million web clients. The web infiltration rate is simply $27 \%$, it is exceptionally low contrasted with nations like Nigeria, Kenya, and Indonesia and so forth. It ought to be in any event $67 \%$.

v. $15 \%$ of Indians have web on their Smartphone. i.e just 154 million individuals with broadband on their smart phones.

vi. $\quad$ Speed of Internet loading is not good at all the places. The normal page load time in China is 2.6 seconds while in India its 5.5 seconds

vii. Increasing PoS Machines. where as India has 1.46 POS million machines only which is quite low. Keeping the above points in mind we can state that India still lacks in infrastructure for a cashless economy.

Modes of Cashless transactions: Cheque, Demand Draft, Online Transactions: NEFT, RTGS, Wallet Cards, UPI Apps, Gift Cards, USSD

\section{OBJECTIVES:}

i. To examine the level of awareness of the implementation of the cashless economy in India

ii. To determine the significance of the use of the cashless economy.

iii. To study the key problems of the cashless economy.

iv. To evaluate their combined effect in cashless economy.

\section{LITERATURE REVIEW}

The literature review helps us to understand the topic and the work being already being undertaken and also helps us know the potential areas or the gap which has been overlooked or left out by others. In reference to the same we have tried to do a literature survey and the review to understand the various aspects of the cashless economy and the related aspects like /demonetizations.

Goel R. et al. (2019) stated that cashless economy is a system where there is no or little or no flow of cash in an economy, and transactions are made using cashless or digital means. In November 2016 the government of India took a very big step of demonetizing 500 and 1000 INR currency. It was done for various reasons like eradication of fake currency, curbing black money, to keep check on tax evasion, and also the essence of the policy is to shift the economy from a cash based economy to a cashless economy. In India, the ratio of currency to gross domestic product was $11.23 \%$ in March 2019.

Bhuvana M and Vasantha. S, (2017). In their study "A Mediating Effect of Demonetization of Currency Notes towards Adopting Cashless Notes towards Adopting Cashless Payment System" proposed that demonetization of currency plays a vital role in the acceptance and the use of technology, online banking system. There are still hurdles which needs considerations like the security, payment experiences. Initially the transactions were done using the credit cards and net.

Garg, Preeti and Panchal, Manvi (2017) stated in their research that Cashless economy plays a significant role in iv. There are only $17 \%$ of Smart phones users in India.

In China there are 4000 POS machines per million people,

the economic growth of our country according to the respondents' responses cashless economy will facilitate in curbing black money, will help in fighting against terrorism , halt at cash robbery , majorly will help in checking black money and will envision counterfeit money.

Garg and Panchal,( 2017) in their study stated that in India managing inflation, maintaining stable pricing and improving the monetary policy is the main focus of the new policy. The proportion of cash to domestic product is higher in our country- $12.42 \%$, China- $9.47 \%$, Brazil-4\%. As compared to other big economies the currency notes in circulation is highest i.e. 76.47 billion-India (2012-13), 34.5 billion- United States.

Boston Consulting Group and Google, conducted a study in July.2017 which stated that credit card users are three times less as compared to wallet users, study also states that mobile banking users have already been left far behind by the wallet users ,

According to Hoehle (2012) in his study stated that internet users are increasing in number and spending more time online because of which banks in most of the countries are providing their banking services online which helps the users perform banking transactions online without being physically present in the banks which also supports the research relating to e-banking focuses on various disciplines of information system, e-commerce ,marketing , business and management

Report by Prince Water House Coopers, (2015). In India people not connected with banks were 233 millions. Since the points of sales which accept payments through cards are only 1.46 million which restricts the people of using their credit cards. Moses- Ashike, (2011) in their study find that e-finance, e-money, e-exchange, and also the e-brokering reflects the type of transactions done in the of cashless economy. They are the different aspects of cashless economy. A. Roth, (2010), research shows that the developed countries are slowly accepting the electronic payment systems (Cards) rather than cash transactions.

Woodford, (2003), When the transactions goods and services are done through the electronic media, it is referred to as cashless economy. Some percent of cash do exists in the cash less economy. . The arguments given by Marco and Bandiera (2004) were that more the cashless banking is done more it strengthens the effectiveness of the monetary policy of the country. It states that the stability of the financial system is not threatened by the current level of emoney usage. But if the fiscal policy is not meticulously considered by the government then central bank may lose control over monetary policy.

\section{RESEARCH METHODOLOGY}

For the study primary and secondary data was collected for the study. Sources of Secondary data considered were the published research papers, articles, and the World Wide Web (Online). A self designed structured, undisguised questionnaire was used to collect the primary data. Areas chosen were mainly the three states of North India i.e. Uttarakhand, Uttar Pradesh and Himachal Pradesh as the rea for study. Uttarakhand and Himachal are the two hilly states of North India. 
The views regarding the cashless economy in North India has been tried to study.

The variable considered are:

Dependent variable: Problems. Independent variables: Awareness and Advantages. A structured, undisguised questionnaire is used to collect the primary data through the internet (email).There were three sections and 24 units. 5 point likert scale was used. Excel is used for the analysis of the primary data.

\section{Sampling Design}

For collecting the primary data simple random sampling( Convenience sampling) was used. More than 150 people were targeted out of which only 116 responses were acceptable at the end from responses received. Electronic

mail was used to send the structured-undisguised questionnaire and receive the responses online.

\section{DATA ANALYSIS}

\section{Content Validity and Reliability}

"Cronbach alpha test" is conducted to check the reliability level of the primary data. Elements with alpha value of 0.70 or above only are considered (Nunnally, 1978). Alpha value is 0.70 which indicates the internal consistency of the scales (Cronbach, 1981).

After the Reliability test which was conducted the value outcome was 0.70

Table 1 represents the demographic profile of the respondents.

Table 1: Demographic Factors of the Respondents.

\begin{tabular}{|c|c|c|}
\hline Demographic Variables & Frequency & \%age \\
\hline Gender Male Female Total & 71 & 63.96 \\
& 41 & 36.93 \\
\hline Age Group & 111 & \\
18-25 years & & 18.01 \\
26-30 years & 20 & 33.33 \\
31-39 years & 37 & 18.01 \\
40 years and above & 20 & 30.63 \\
Total & 34 & \\
\hline Level Of Education & 111 & \\
Intermediate & 15 & 13.51 \\
Graduate & 15 & 13.51 \\
Post Graduate & 56 & 50.45 \\
Doctorate & 25 & 22.52 \\
Total & 111 & \\
Occupation & & \\
Center Government Employee State & 6 & 5.40 \\
Government Employee & 4 & 3.60 \\
Private Organization Employee & 59 & 53.15 \\
Self Employed & 30 & 27.02 \\
Other & 12 & 10.81 \\
Total & 111 & \\
\hline Annual Income & 35 & 31.53 \\
Less Than 1 Lakh & 47 & 42.34 \\
1Lakh- 5 Lakh & 29 & 26.12 \\
More than 5 Lakh & 111 & \\
Total & & \\
\hline
\end{tabular}

Interpretation: It is clear from the above table that from a total of 111 valid respondents $63.96 \%$ were males and $36.93 \%$ were females Out of them $50.45 \%$ were Post Graduates, $22.52 \%$ were Doctorate and $13.51 \%$ were Graduates and Intermediates.

It is also seen that $53.15 \%$ of the respondents were doing jobs in Private organizations, $27.02 \%$ were self employed and $5.40 \%$ and $3.60 \%$ were employed in Center government and Sate government departments respectively.

\section{Chart: 1}

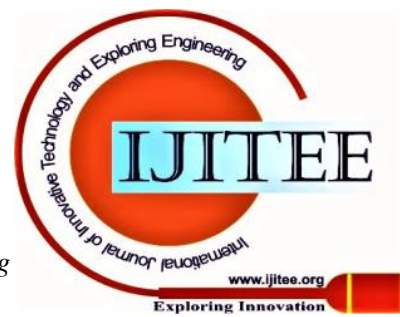


Implementation of Cashless Economy: Measuring the Impact of Awareness and Advantages with Problems with Reference to North India

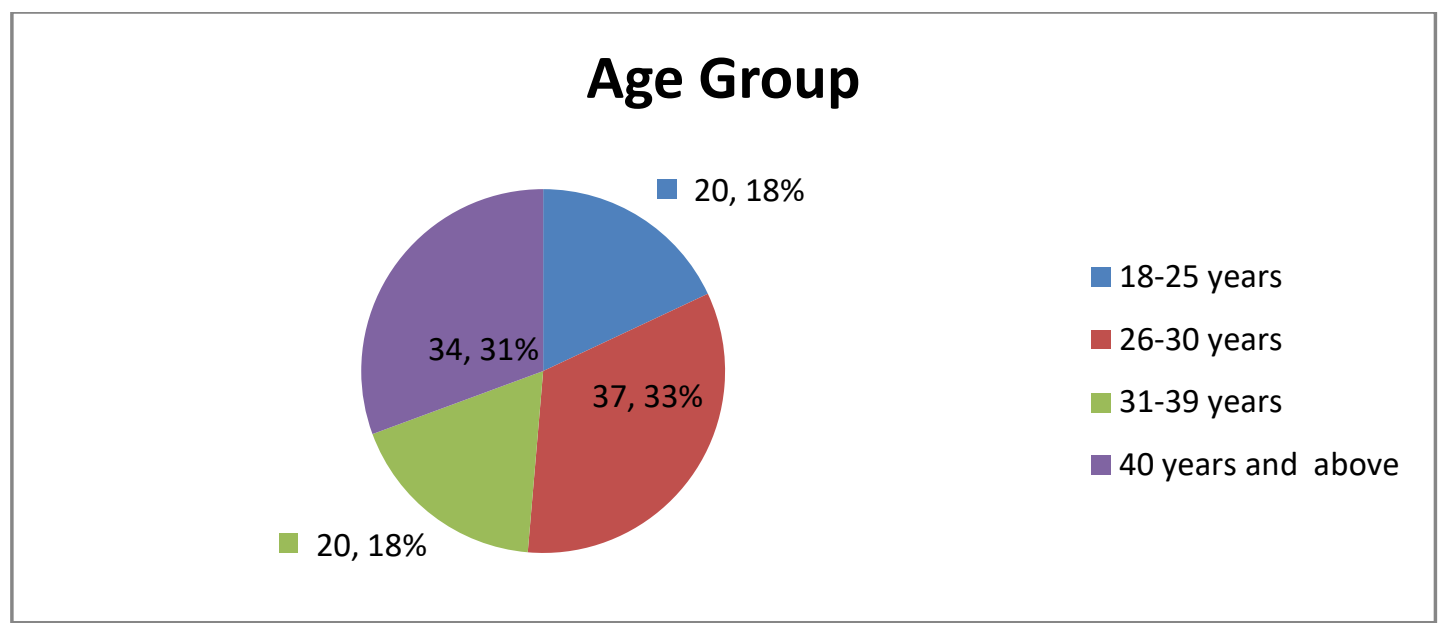

\section{HYPOTHESIS:}

$\mathrm{H}_{\mathrm{o}}$ : Problems are not affected with awareness and advantages in the cashless economy in India. $\mathrm{H}_{1}$ : Problems are affected with awareness and advantages in the cashless economy in India.

Table 2: ANOVA: Single Factor

\begin{tabular}{|l|c|c|c|c|}
\hline Groups & Number of Respondents & Total & Average & Std Dev. \\
\hline Awareness & 111 & 491.000 & 4.423 & 0.3507 \\
\hline Advantage & 111 & 492.933 & 4.441 & 0.2345 \\
\hline Problems & 111 & 502.667 & 4.529 & 0.2665 \\
\hline
\end{tabular}

ANOVA

\begin{tabular}{|l|l|l|l|l|l|l|}
\hline $\begin{array}{l}\text { Sources } \\
\text { Of } \\
\text { Variation }\end{array}$ & Sum of Squares & $\begin{array}{l}\text { Degreeo } \\
\text { f } \\
\text { freedom }\end{array}$ & $\begin{array}{l}\text { Mean Sum of } \\
\text { Squares }\end{array}$ & F value & p-value & $\begin{array}{l}\text { F- } \\
\text { critic } \\
\text { al }\end{array}$ \\
\hline $\begin{array}{l}\text { Between } \\
\text { Groups }\end{array}$ & 0.7045 & 2 & 0.35223 & 4.2484 & 0.01508 & 3.023 \\
\hline $\begin{array}{l}\text { Within } \\
\text { Groups }\end{array}$ & 27.3603 & 330 & 0.08291 & & & 09 \\
\hline Total & 8.0647 & 332 & & & & \\
\hline
\end{tabular}

Interpretation of Table 2: It is evident from the above ANOVA table that p-value is very small i.e. $\mathrm{p}<0.05$ and the value of $F_{\text {crit. }}(3.023097)<\mathrm{F}$ ( 4.24837) hence results are statistically significant. Null Hypothesis is not accepted, since the result is significant we can say that there is a ration ship between the three variables.

Reject $\mathrm{H}_{\mathrm{o}}$

Chart : 2 Total of Responses of 111 Respondents

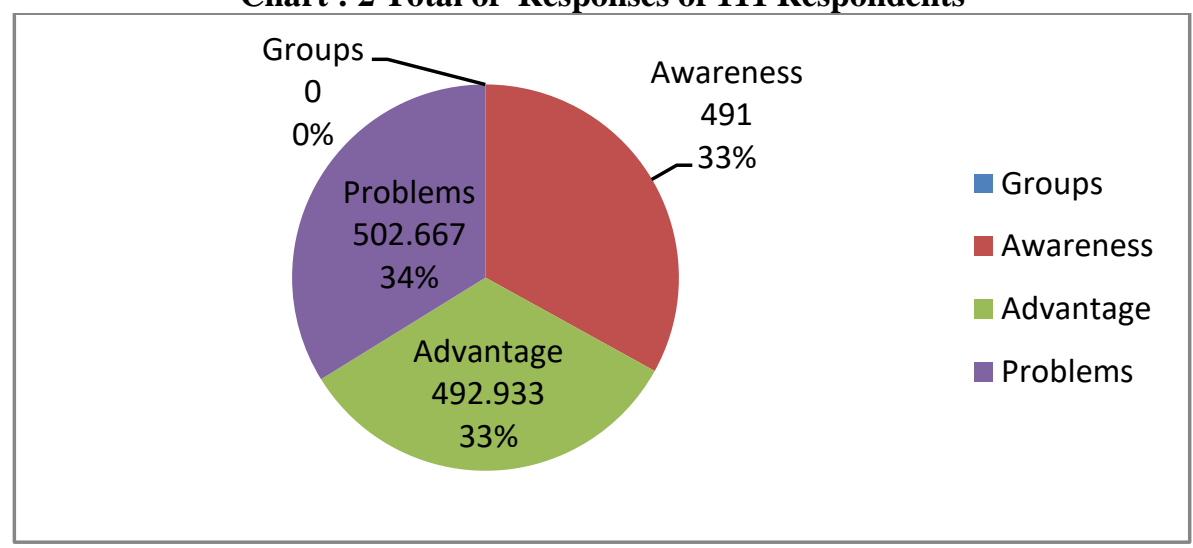


Table 3: Regression Analysis of All Three Variables

\begin{tabular}{|c|c|}
\hline Multiple R & 0.501 \\
\hline R Square & 0.251 \\
\hline Adjusted R Square & 0.237 \\
\hline Standard Error & 0.232 \\
\hline Observations & 111.000 \\
\hline Multiple R & 0.501 \\
\hline
\end{tabular}

ANOVA

\begin{tabular}{|c|c|c|c|c|c|c|}
\hline & $\begin{array}{l}\text { Degree of } \\
\text { freedom }\end{array}$ & $\begin{array}{l}\text { Sum of } \\
\text { Squares }\end{array}$ & \multicolumn{2}{|c|}{$\begin{array}{l}\text { Mean Sum of } \\
\text { Squares }\end{array}$} & F-value & $\begin{array}{l}\text { Significanc } \\
\text { e F }\end{array}$ \\
\hline Regression & 2 & 1.9486 & \multicolumn{2}{|l|}{0.9743} & 18.0731 & $\begin{array}{l}1.69635 \mathrm{E}- \\
07\end{array}$ \\
\hline Residual & 108 & 5.82212 & \multicolumn{2}{|l|}{0.0539} & & \\
\hline Total & 110 & 7.7708 & & & & \\
\hline & Coefficients & $\begin{array}{l}\text { Standard } \\
\text { Error }\end{array}$ & t Stat & $\begin{array}{l}\text { P- } \\
\text { value }\end{array}$ & Lower $95 \%$ & Upper $95 \%$ \\
\hline Intercept & 1.8397 & 0.4600 & 3.9998 & 0.0001 & 0.9280 & 2.7514 \\
\hline Awareness & 0.0736 & 0.0648 & 1.1349 & 0.2589 & -0.0549 & 0.2021 \\
\hline Advantage & 0.5322 & 0.0970 & 5.4850 & 0.0000 & 0.3399 & 0.7245 \\
\hline
\end{tabular}

Interpretation of Table 3: The regression analysis of the primary data clearly signifies that there exist a relationship amongst the three constructs but it's not very high since correlation coefficient between them is only .501 which is average. It is evident that we are able to explain only $25 \%$ variability in the variable which represents the goodness of fit. From the ANOVA table, significance F $=1.69635 \mathrm{E}-07$ extremely very less, signifies that the regression analysis is good and the (extremely small) $\mathrm{p}<0.05$. The intercept is
$99.99 \%$ correct, since the level of significance taken was $5 \%$. It clearly signifies that when the combined effect is analyzed between the dependent and the independent variables it shows a positive result.

$\mathrm{H}_{0 \text { : }}$ Awareness of the people has an effect on the problems in cashless economy.

$\mathrm{H}_{1}$ : Awareness of the people has no effect on the problems in the cashless economy

Table 4: Regression Statistics: Awareness with Problems

\begin{tabular}{|c|c|}
\hline Multiple R & 0.2050528 \\
\hline R Square & 0.042046651 \\
\hline Adjusted R Square & 0.033258088 \\
\hline Standard Error & 0.26133103 \\
\hline
\end{tabular}

\begin{tabular}{|l|l|l|l|l|l|}
\hline & $\begin{array}{l}\text { Degree of } \\
\text { freedom }\end{array}$ & $\begin{array}{l}\text { Sum of } \\
\text { Squares }\end{array}$ & $\begin{array}{l}\text { Mean sum of } \\
\text { squares }\end{array}$ & F-value & Significance F \\
\hline $\begin{array}{l}\text { Regressio } \\
\mathbf{n}\end{array}$ & 1 & 0.3267 & 0.3267 & 4.7842 & 0.0309 \\
\hline Residual & 109 & 7.4440 & 0.0683 & & \\
\hline Total & 110 & 7.7708 & & & \\
\hline
\end{tabular}

\begin{tabular}{|l|l|l|l|l|l|l|}
\hline & \multicolumn{1}{|c|}{ Coefficients } & $\begin{array}{c}\text { Standard } \\
\text { Error }\end{array}$ & t Stat & P-value & Lower 95\% & $\begin{array}{c}\text { Upper } \\
\text { 95\% }\end{array}$ \\
\hline Intercept & 3.8415 & 0.3151 & 12.1917 & $4.35 \mathrm{E}-22$ & 3.2170 & 4.4660 \\
\hline $\begin{array}{l}\text { Awarenes } \\
\text { S }\end{array}$ & 0.1553 & 0.0710 & 2.1873 & 0.0309 & 0.0146 & 0.2961 \\
\hline
\end{tabular}

Interpretation of Table 4: The above table indicates that the effect of Awareness on the awareness only $20 \%$. Significance F $(0.030857)<.05$, indicates that the regression analysis is good. $p$ value (4.3506E-22)is extremely low and also in case of Awareness the $p$ value is again very less. The intercept is significant. i.e. $99.99 \%$ correct. We do not accept the Null Hypothesis.

Published By:

Blue Eyes Intelligence Engineering

and Sciences Publication

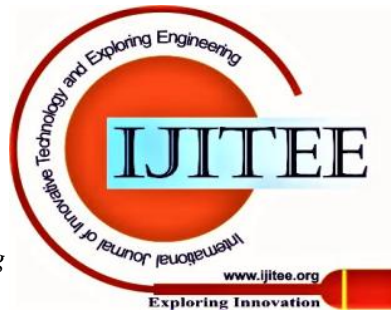


Implementation of Cashless Economy: Measuring the Impact of Awareness and Advantages with Problems with Reference to North India

It clearly indicates that there exists a relationship between the dependent and the independent variable but there are other factors which have an effect on the problems.
$\mathrm{H}_{0}$ : Advantages are correlated with the problems in cashless economy in India

$\mathrm{H}_{1}$ : Advantages are not correlated with the problems in cashless economy in India

Table 5: Regression Statistics: Advantage and Problems

\begin{tabular}{|c|c|}
\hline Multiple R & 0.49176 \\
\hline R Square & 0.2418 \\
\hline Adjusted R Square & 0.2349 \\
\hline Standard Error & 0.2325 \\
\hline
\end{tabular}

\begin{tabular}{|c|c|c|c|c|c|}
\hline & $\begin{array}{l}\text { Degree of } \\
\text { freedom }\end{array}$ & $\begin{array}{c}\text { Sum of } \\
\text { squares }\end{array}$ & $\begin{array}{c}\text { Mean Sum of } \\
\text { Squares }\end{array}$ & F-value & Significance F \\
\hline Regression & 1 & 1.8792 & 1.8792 & 34.7665 & $4.2303 \mathrm{E}-08$ \\
\hline Residual & 109 & 5.8916 & 0.0541 & & \\
\hline Total & 110 & 7.7708 & & & \\
\hline
\end{tabular}

\begin{tabular}{|l|l|l|l|l|l|l|}
\hline & Coefficients & $\begin{array}{l}\text { Standard } \\
\text { Error }\end{array}$ & t Stat & P-value & $\begin{array}{l}\text { Lower } \\
\mathbf{9 5 \%}\end{array}$ & Upper 95\% \\
\hline Intercept & 2.052726968 & 0.4205 & 4.8820 & $3.61697 \mathrm{E}-06$ & 1.2194 & 2.8861 \\
\hline Advantage & 0.557507384 & 0.0946 & 5.8963 & $4.2303 \mathrm{E}-08$ & 0.3701 & 0.7449 \\
\hline
\end{tabular}

Interpretation of Table 5: The relationship between the advantage and the problems is approx 50\%. Significance $\mathrm{p}(4.2303 \mathrm{E}-08)<.05$, is extremely low indicating the goodness of regression analysis. p value (3.61697E-06)is extremely low, we can accept the intercept, in case of
Advantage the $\mathrm{p}$ value is again very less. The intercept is significant. i.e. $99.99 \%$ correct.. The relationship between the advantage and the problems is much more as compared to the awareness. Reject the Null Hypothesis

Table 6: Regression Statistics: Awareness and Advantage

\begin{tabular}{|c|c|}
\hline Multiple R & 0.2299 \\
\hline R Square & 0.0529 \\
\hline Adjusted R Square & 0.0442 \\
\hline Standard Error & 0.2292 \\
\hline
\end{tabular}

\begin{tabular}{|l|l|l|l|l|l|}
\hline & $\begin{array}{l}\text { Degree of } \\
\text { freedom }\end{array}$ & $\begin{array}{l}\text { Sum of } \\
\text { Squares }\end{array}$ & $\begin{array}{l}\text { Mean Sum of } \\
\text { Squares }\end{array}$ & F-value & Significance F \\
\hline Regression & 1 & 0.3196 & 0.3196 & 6.0833 & 0.0152 \\
\hline Residual & 109 & 5.7264 & 0.0525 & & \\
\hline Total & 110 & 6.0460 & & & \\
\hline
\end{tabular}

\begin{tabular}{|l|l|l|l|l|l|l|}
\hline & Coefficients & $\begin{array}{l}\text { Standard } \\
\text { Error }\end{array}$ & t Stat & P-value & Lower 95\% & $\begin{array}{l}\text { Upper } \\
\mathbf{9 5 \%}\end{array}$ \\
\hline Intercept & 3.7613 & 0.2764 & 13.6105 & $2.99 \mathrm{E}-25$ & 3.2136 & 4.3095 \\
\hline Advantage & 0.1536 & 0.0623 & 2.4664 & 0.0152 & 0.0302 & 0.2774 \\
\hline
\end{tabular}

). P-values of both the intercept and the advantage

Interpretation of Table 6: The correlationcoefficient between the variables is approx 0.229. Regression analysis is good (Significance $-\mathrm{F}$ is low is low hence we can say that the coefficients are 99.99\% correct. Reject the Null Hypothesis.

Table 7: Correlation

\begin{tabular}{|c|c|c|c|}
\hline & Awareness & Advantage & Problems \\
\hline Awareness & 1 & & \\
\hline Advantage & 0.2299 & 1.00000 & \\
\hline Problems & 0.2051 & 0.4918 & 1.00000 \\
\hline
\end{tabular}




\section{CONCLUSION}

According to the analysis of the data -Awareness of the implementation amongst the people, of the cashless economy in India is $84.38 \%$.In their view the significance of the use of the cashless economy is $77.24 \%$. The key Problems in the economy to be faced is $84.11 \%$. It is seen that awareness and the benefits are not only the factors which affects the success of the cashless economy. Although they do have a relationship with the problems faced by the people and the government. There are many other factors related to the problems in cashless economy. It has been observed from the above study that India has taken a leap towards the cashless society. At initial stage there are a number of obstacles which have to be worked upon by the government. People are in a state of ambiguity, having lack of awareness regarding knowledge, and the benefits of cashless transactions. The confidence of people on cashless transaction is necessary. It is very clear that the infrastructure, the set up required to become efficient and fully cashless economy is still lacking especially in rural and hilly regions of India and it's a long journey to go. On the other hand urban population is optimistic and a large part have appreciated the actions taken by the government, but the gap between the rural and urban India still exist in terms of infrastructure, views and practices of people which has to be seriously worked upon. People are of the views that it's a good step toward the county's economic development. If we want the people in general to shift towards the cashless transactions, the government, banking system and the related service providers will have to be seriously and continuously updated and improve the technology. Security, ease and safety of transactions being the major issues. The trust in people should be developed.

After a year of demonetization it has been observed that people in urban India are getting in habit of using the online transactions and using the apps like "Pay tm", debit cards and credit cards for payments at shopping malls, booking railway tickets, at petrol pumps, movie tickets paying EMIs, online transfer of money like RTGS etc. It is so since they are more familiar with internet and android phones. But in rural areas the things are still not so bright. It will take some time to make them come in the stream. It will happen if they understand the significance of cashless economy.

\section{LIMITATIONS}

i. Secondary data on the related topics were very limited since the concept of cashless economy in India is of recent origin.

ii. It was not easy to collect the primary data. People were not aware of the cashless economy and its benefits.

iii. The study is restricted to the three states of North India only.

\section{REFERENCES:}

1. Dr. P. Abirami and S. Senthil Kumar, Electronic Payment SystemsTechnical and Strategic

2. Issues. (2017)International Journal of Management, 8 (2), pp. 77-80.

3. Dr. Subramanian.S, Paper- Free Payment Systems In India-An Analytical Study, Volume

4. 5, Issue 1, January (2014), pp. 80-87, International Journal of Management (IJM).

5. Goel R. et al., Moving from cash to cashless economy: A digital study of consumer perception towards digital transactions. IJRTE (international journal of recent technology and engineering) ISSN:
2277-3878, volume-8, Issue: 1, May 19.

file:///C:/Users/admin/Downloads/cash\%20to\%20cashless\%20econo my.pdf

6. Garg P., and Panchal. M ,- Study on Introduction of Cashless Economy in India (2016). Benefits \& Challenge's .Journal of Business and Management (IOSR), e-ISSN: 2278-487X, p-ISSN: 2319-7668. Volume 19, Issue 4. Ver. II , Apr. 2017, PP 116-120.

7. Hoehle H, Scornavacca E, Huff S (2012) Three decades of research on consumer adoption and utilization of electronic banking channels A literature analysis. Decision Support Systems 54: 122-132.

8. Moses-Ashike, H- Cashless Economic can Reduce Risk of Carrying Huge Cash, [Online] (2011).Available: http://www.businessdayonline.com/.../22217.

9. Manpreet Kaur, DEMONETIZATION: IMPACT ON CASHLESS PAYEMNT SYSTEM, (2017). 6th International Conference on Recent Trends in Engineering, Science and Management, ISBN: 97893-86171-21-4.

10. Martin Anane Felix Oppong Asamoah, Customers' Satisfaction and Attitude towards Electronic Banking Services in Ghana: A Case Study of Selected Banks in Kumasi

11. Metropolis, (2015). European Journal of Business and Management, ISSN 2222-1905 (Paper) ISSN 2222-2839 (Online), Vol.7, No.32.

12. Marco, A. \& L. Bandiera, -Monetary Policy, Monetary Areas and Financial Development with Electronic Money, IMF Working Study, IMF., (2004).

13. Roth, B. L.- The Future of Money: The Cashless Economy - Part 1\|. [Online](2010).Available: https://www.x.com/.../future-moneycashless-economy-part-i.

14. Woodford M. - Interest \& Price: Foundation of a Theory of Monetary Policy\|l(2003). Princeton University Press.

15. Yogesh Kumawat, Customers Attitude towards E-Banking System in Rajasthan, IOSR. (2014). Journal of Business and Management (IOSR-JBM) e-ISSN: 2278-487X, p-ISSN: 2319-7668. Volume 16 Issue 9.Ver. III, PP 08-14

16. http://economictimes.indiatimes.com/wealth/spend/ready-to-gocashless/articleshow/56269830.cms

17. http://economictimes.indiatimes.com/topic/cashless-transactions.

18. https://www.sarkariyojna.co.in/10-cashless-digital-paymentsmethods-cashless-india/

19. 16. http://moneyexcel.com/15775/10-best-cashless-payment-methods 